\title{
No significant interactions between nitrogen stimulation and ozone inhibition of isoprene emission in Cathay poplar
}

\author{
Xiangyang Yuan a,b,c, Bo Shang a,b , Yansen Xu ${ }^{\mathrm{a}, \mathrm{b}}$, Yue Xin ${ }^{\mathrm{a}, \mathrm{b}, \mathrm{d}}$, Yuan Tian ${ }^{\mathrm{e}}$, \\ Zhaozhong Feng a,b,c,*, Elena Paoletti ${ }^{\mathrm{a}, \mathrm{f}}$ \\ a State Key Laboratory of Urban and Regional Ecology, Research Center for Eco-Environmental Sciences, Chinese Academy of Sciences, Beijing 100085, China \\ b College of Resources and Environment, University of Chinese Academy of Sciences, Beijing 100049, China \\ c State Key Laboratory of Desert and Oasis Ecology, Xinjiang Institute of Ecology and Geography, Chinese Academy of Sciences, Urumqi 830011, China \\ ${ }^{\mathrm{d}}$ Key Laboratory of Land Surface Pattern and Simulation, Institute of Geographic Sciences and Natural Resources Research, Chinese Academy of Sciences, Beijing 100101, China \\ e School of Food, Beijing Technology and Business University, Beijing 100048, China \\ ${ }^{\mathrm{f}}$ CNR, Via Madonna del Piano 10, 50019 Sesto Fiorentino, Florence, Italy
}

\section{H I G H L I G H T S}

- The combined effect of $\mathrm{O}_{3}$ and $\mathrm{N}$ on isoprene emission was investigated firstly.

- Elevated $\mathrm{O}_{3}$ decreased and $\mathrm{N}$ load increased isoprene emission of poplar.

- Correlation between isoprene emission and $A_{\text {sat }}$ did not change with $\mathrm{N}$ load.

- $\mathrm{N}$ load did not mitigate the negative effects of $\mathrm{O}_{3}$ on isoprene emission.

\section{G R A P H I C A L A B S T R A C T}

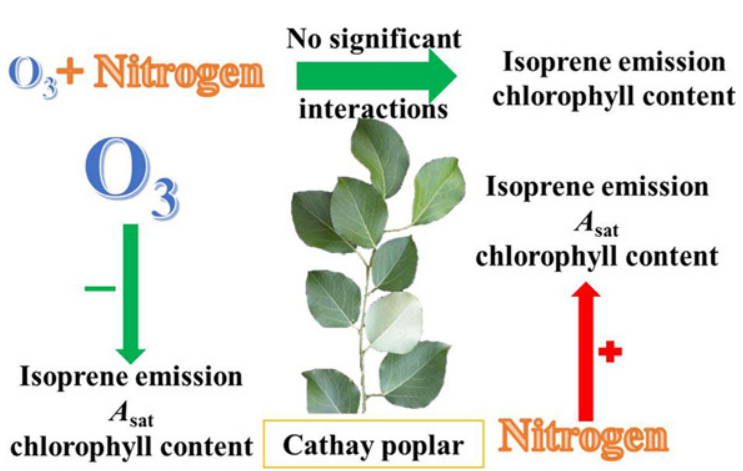

\section{A R T I C L E I N F O}

\section{Article history:}

Received 13 March 2017

Received in revised form 13 May 2017

Accepted 15 May 2017

Available online 26 May 2017

Editor: Jay Gan

\section{Keywords:}

Isoprene emission

Tropospheric $\mathrm{O}_{3}$

Nitrogen deposition

Photosynthesis

Poplar

\begin{abstract}
A B S T R A C T
Isoprene emission from plants subject to a combination of ozone $\left(\mathrm{O}_{3}\right)$ and nitrogen $(\mathrm{N})$ has never been investigated. Cathay poplar (Populus cathayana) saplings were exposed to $\mathrm{O}_{3}(\mathrm{CF}$, charcoal-filtered air, NF, non-filtered ambient air and $\mathrm{E}^{-} \mathrm{O}_{3}$, non-filtered air $\left.+40 \mathrm{ppb}\right)$ and $\mathrm{N}$ treatments $\left(\mathrm{N} 0,0 \mathrm{~kg} \mathrm{~N} \mathrm{ha}^{-1}\right.$ year $^{-1}$, N50, $50 \mathrm{~kg} \mathrm{~N}^{-1}$ year $^{-1}$ and $\mathrm{N} 100,100 \mathrm{~kg} \mathrm{~N}^{-1}$ year $^{-1}$ ) for 96 days. Increasing $\mathrm{O}_{3}$ exposure decreased isoprene emission ( $11.5 \%$ in NF and $57.9 \%$ in $\left.\mathrm{E}-\mathrm{O}_{3}\right)$, as well as light-saturated photosynthetic rate $\left(A_{\text {sat }}\right)$ and chlorophyll content, while $\mathrm{N}$ load increased isoprene emission (19.6\% in N50 and 33.4\% in N100) as well as $A_{\text {sat }}$ and chlorophyll content. Although $\mathrm{O}_{3}$ and $\mathrm{N}$ interacted significantly in $A_{\text {sat }}, \mathrm{N}$ did not mitigate the negative effects of $\mathrm{O}_{3}$ on isoprene emission, i.e. the combined effects were additive and did not interact. These results warrant more research on the combined effects of co-existing global change factors on future isoprene emission and atmospheric chemical processes.
\end{abstract}

(c) 2017 Elsevier B.V. All rights reserved.

* Corresponding author at: State Key Laboratory of Urban and Regional Ecology, Research Center for Eco-Environmental Sciences, Chinese Academy of Sciences, Beijing 100085, China. E-mail address: fzz@rcees.ac.cn (Z. Feng). 


\section{Introduction}

Increasing tropospheric ozone $\left(\mathrm{O}_{3}\right)$ concentration has become a common concern in northern mid-latitudes after the Industrial Revolution (Cooper et al., 2014; Hartmann et al., 2013). Recent observations and modeling results point towards a decrease in hourly peak $\mathrm{O}_{3}$ concentrations in many parts of Europe and North America (Cooper et al., 2015; Dentener et al., 2010; Paoletti et al., 2014; Sicard et al., 2016), while the values are increasing in many Asian regions (Ding et al., 2008; Wang et al., 2009; Huang et al., 2015; Revell et al., 2015). Feng et al. (2015) indicated that tropospheric $\mathrm{O}_{3}$ concentration in large regions of China will likely continue to rise in the immediate future due to the high $\mathrm{O}_{3}$-precursor emission rates, e.g. nitrogen oxides (NOx). Nitrogen $(\mathrm{N})$ deposition is another serious issue of global environmental change. A global transport-chemistry model projects that global $\mathrm{N}$ deposition will likely double the existing levels by 2050 (Galloway et al., 2004), especially in China, which is the major manufacturer and emitter of reactive $\mathrm{N}$ in the world (Liu et al., 2011). Between 1980 and 2000, the average bulk $\mathrm{N}$ deposition of China increased by about $60 \%$ per year, reaching an annual deposition to soil of $21.1 \mathrm{~kg} \mathrm{~N} \mathrm{ha}^{-1}$ (Liu et al., 2013). In some areas of southeast China, $\mathrm{N}$ deposition rates have reached $30-50 \mathrm{~kg} \mathrm{~N}^{-1}$ year $^{-1}$ (Fan et al., 2007; Liu et al., 2011) and are expected to increase with rising fuel combustion and production and utilization of nitrogenous fertilizer (Liu et al., 2011, 2013).

Both the above-mentioned pollutants are known to co-occur in the environment and affect the biodiversity and function of forest ecosystems (Ainsworth et al., 2012; Sutton et al., 2014). Enhanced $\mathrm{O}_{3}$ pollution reduces photosynthesis, decreases plant growth, and induces common effects such as visible injuries (Feng and Kobayashi, 2009; Feng et al., 2014; Wittig et al., 2009). Enriched N nutrition is usually beneficial under $\mathrm{O}_{3}$ stress as a result of increased photosynthetic activity (i.e. photosynthetic enzyme activity) and biomass production (Häikiö et al., 2007; Handley and Grulke, 2008). However, N inputs may exceed critical loads, i.e. low levels of $\mathrm{N}$ load increase plant production while high levels may render plants more susceptible to pollutants and natural environmental stressors (Cardoso-Vilhena and Barnes, 2001). Moreover, such $\mathrm{O}_{3}$ and $\mathrm{N}$ induced changes in the growth and metabolism of plants may affect the emission of biogenic volatile organic compounds (BVOCs) emitted by plants (Loreto and Schnitzler, 2010) due to a clear link between BVOC and photosynthesis (Sharkey and Yeh, 2001). There is thus a need to further investigate the correlation between BVOC emission and physiological parameters under the effects of elevated $\mathrm{O}_{3}$ pollution and $\mathrm{N}$ load.

Plants collectively produce thousands of BVOCs, of which isoprene is the most represented component of the biosphere-atmosphere interactions (Sharkey and Monson, 2017). This compound accounts for about $50 \%$ of the total emission of BVOCs into the atmosphere (Guenther et al., 1995), and plays important roles in plant response to abiotic and biotic stresses (Filella et al., 2013; Holopainen and Gershenzon, 2010) and in the chemistry of the atmosphere. In the atmosphere, isoprene is a precursor of $\mathrm{O}_{3}$, peroxyacetyl nitrates and secondary organic aerosols (Claeys et al., 2004; Paasonen et al., 2013). Given the important interaction between phytogenic isoprene emission and global climate change, there is great interest in detecting how realistic combinations of global change factors affect the emission of isoprene from vegetation.

The research on isoprene emission under elevated $\mathrm{O}_{3}$ or $\mathrm{N}$ deposition has been previously conducted separately, and the results are sometimes conflicting (Peñuelas and Staudt, 2010). Previous studies reported that elevated $\mathrm{O}_{3}$ levels may increase, decrease, or do not change isoprene emission (Calfapietra et al., 2008; Fares et al., 2006, 2010; Llusià et al., 2002; Peñuelas and Staudt, 2010). Compared to $\mathrm{O}_{3}$, knowledge on $\mathrm{N}$ load effects on isoprene emission is even more limited. Most of previous studies on $\mathrm{N}$ effects on BVOCs were focused on monoterpenes or sesquiterpenes, and the results were inconsistent. Blanch et al. (2007) found that the emissions of terpene from Pinus halepensis and Quercus ilex decreased under high N load, while Kainulainen et al.
(2000) indicated that $\mathrm{N}$ availability did not affect monoterpene production in Scots pine (Pinus sylvestris) and Norway spruce (Picea abies). For isoprene, only a couple of old studies reported that increasing $\mathrm{N}$ availability stimulated isoprene emission in velvet beans (Mucuna sp.) (Harley et al., 1994) and in aspen and white oak trees (Litvak et al., 1996). Research on the combined effect of $\mathrm{O}_{3}$ and $\mathrm{N}$ on BVOC emission is also very limited. Recently, Llusià et al. (2014) reported that individu$\mathrm{al}_{3}$ and $\mathrm{N}$ reduced the emission of terpenes in two Mediterranean leguminous species (Ornithopus compressus and Trifolium striatum), while the effect of the combination was not significantly interactive in any of the two species. Carriero et al. (2016) observed that $\mathrm{O}_{3}$ exposure increased BVOC emission from a monoterpene-emitter (Betula pendula), the effect of $\mathrm{N}$ depended on the individual monoterpene, and the combined effects of $\mathrm{O}_{3}$ exposure and $\mathrm{N}$ load on BVOC emission were additive, i.e. did not show significant interactions. To our knowledge, no previous papers have considered the effects of a combination of $\mathrm{O}_{3}$ exposure and $\mathrm{N}$ load on isoprene emission from plants.

Poplars are widespread deciduous plants in temperate and boreal forests and significant isoprene emitters (Kesselmeier and Staudt, 1999). In China, poplar is a native species, which covers $>10$ million ha (Xu et al., 2009). In this study, the combined effect of elevated $\mathrm{O}_{3}$ and $\mathrm{N}$ load on the isoprene emission of Cathay poplar (Populus cathayana) was investigated. We tested the hypotheses that: (1) elevated $\mathrm{O}_{3}$ decreased and $\mathrm{N}$ load increased isoprene emission of Cathay poplar, and the effects were additive, i.e. did not show significant interactions; and (2) isoprene emission was affected by stress-driven modifications in photosynthetic parameters (carbon assimilation, stomatal conductance, pigment content and intercellular $\mathrm{CO}_{2}$ concentration) and this effect did not change under the combination of $\mathrm{O}_{3}$ and $\mathrm{N}$. In detail, we tested whether $\mathrm{N}$ load altered the response of isoprene emission to accumulated $\mathrm{O}_{3}$ exposure and whether the combination of $\mathrm{N}$ load and $\mathrm{O}_{3}$ exposure uncoupled the usual correlations between photosynthetic parameters and isoprene emission.

\section{Materials and methods}

\subsection{Plant materials and treatments}

Rooted cuttings of Cathay poplar were raised in 1-L peat containers in a greenhouse in Spring 2015. After 30 days, they were moved to the experimental research site (Changping, northwest of Beijing, $40^{\circ} 19^{\prime} \mathrm{N}$, $116^{\circ} 13^{\prime} \mathrm{E}$ ) and planted to 20 -L pots filled with sandy loam soil $\left(0.95 \mathrm{~g} \mathrm{~N} \mathrm{~kg}^{-1}\right)$ on May 2nd, 2015. The soil was excavated from a nearby farmland at $0-10 \mathrm{~cm}$ depth, sieved out by a $0.3 \mathrm{~mm}$ pore mesh, and then carefully mixed for homogeneity. Nine open-top chambers (OTCs, $12.5 \mathrm{~m}^{2}$ ) with octagonal shape were used. In order to acclimatize to the environment inside the OTCs, cuttings with similar stem length and diameter were randomly located in the OTCs for 10 days. In total, there were 15 plants in each OTC, i.e. five plants for each of three $\mathrm{N}$ levels. Plants were moved weekly within each chamber in order to minimize the effects of microclimate.

Three $\mathrm{O}_{3}$ treatments were applied: charcoal-filtered ambient air (CF), non-filtered ambient air (NF), and NF with addition of $40 \mathrm{ppb}$ $\left(\mathrm{E}-\mathrm{O}_{3}\right)$. Each $\mathrm{O}_{3}$ treatment had three OTC replicates. The $\mathrm{O}_{3}$ fumigation

Table 1

Summary of mean daytime $\mathrm{O}_{3}$ concentrations ( $\mathrm{ppb}, \pm \mathrm{SD}$ ) and AOT40 (ppm h, \pm SD) during the experiment (from June 5 th to September 8th, 2015) in charcoal-filtered air (CF), non-filtered air (NF) and NF $+40 \mathrm{ppb}\left(\mathrm{E}-\mathrm{O}_{3}\right)$ treatments.

\begin{tabular}{lll}
\hline Target & $\begin{array}{l}\text { 10-h average } \mathrm{O}_{3} \\
8: 00-18: 00(\mathrm{ppb})\end{array}$ & $\begin{array}{l}\text { AOT40 } \\
(\mathrm{ppm} \mathrm{h})\end{array}$ \\
\hline $\mathrm{CF}$ & $34.3 \pm 2.30$ & $4.4 \pm 0.45$ \\
$\mathrm{NF}$ & $52.1 \pm 0.57$ & $16.0 \pm 0.38$ \\
$\mathrm{E}-\mathrm{O}_{3}$ & $80.3 \pm 5.50$ & $38.7 \pm 0.61$ \\
\hline
\end{tabular}


experiment lasted 96 days from June 5th to September 8th, 2015. The details about the $\mathrm{O}_{3}$ fumigation procedure were described in $\mathrm{Hu}$ et al. (2015) and Yuan et al. (2016). Table 1 shows the mean daytime $\mathrm{O}_{3}$ concentrations and AOT40 (accumulated $\mathrm{O}_{3}$ exposure over an hourly threshold of $40 \mathrm{ppb}$ ) for the three $\mathrm{O}_{3}$ treatments. Due to high ambient $\mathrm{O}_{3}$ concentration during the growing season, the average daytime $\mathrm{O}_{3}$ concentration was high even in the $\mathrm{CF}(34.3 \pm 2.3 \mathrm{ppb})$. The 10 -h average $\mathrm{O}_{3}$ concentration was $12.8 \%$ lower than the targeted $\mathrm{O}_{3}$ concentration in $\mathrm{E}_{-} \mathrm{O}_{3}$ (Table 1).

Nitrogen treatments also had three levels: N0, $0 \mathrm{~kg} \mathrm{~N}^{-1} \mathrm{year}^{-1}$, $\mathrm{N} 50,50 \mathrm{~kg} \mathrm{~N} \mathrm{ha}^{-1}$ year $^{-1}$ and $\mathrm{N} 100,100 \mathrm{~kg} \mathrm{~N}^{-1}$ year $^{-1}$. For each treatment, applications were carried out five times (June 24th, July 12th, July 31st, August 20th, and September 5th, 2015) as $0.089 \mathrm{~g}$ and $0.178 \mathrm{~g}$ urea dissolved in $100 \mathrm{ml}$ water per time for N50 and N100, respectively. At the end of the experiment, N50 and N100 received $0.208 \mathrm{~g}$ and $0.416 \mathrm{~g} \mathrm{~N}$, compared to the background $0 \mathrm{~g} \mathrm{~N}$. All plants (135 plants in total) were irrigated regularly at one- or two-day intervals in order to keep the soil moisture.

\subsection{Measurement of gas exchange parameters and isoprene emission}

Over 7 consecutive days (i.e. from August 13th to August 19th, 2015), a portable photosynthetic system fitting with circular $2-\mathrm{cm}^{2}$ fluorescence leaf cuvette (LI-6400-40, LI-COR Corp., USA) was used to measure gas exchange and then sample isoprene emission from fullyexpanded leaves from the middle layer of the canopy (one leaf per plant, two plants per treatment in each OTC, 54 samples in total) during the central hours of the day (10:00 a.m.-03:00 p.m.). Photosynthetically active radiation (PAR) was kept constant at $1200 \mu \mathrm{mol} \mathrm{m} \mathrm{m}^{-2} \mathrm{~s}^{-1}$; the block temperature was set at environmental temperature $\left(31-35^{\circ} \mathrm{C}\right)$. Relative humidity was maintained in the range of $40-60 \%$, and ambient $\mathrm{CO}_{2}$ was set at $390 \mathrm{ppm}$. The parameters obtained were the lightsaturated rate of $\mathrm{CO}_{2}$ assimilation $\left(A_{\mathrm{sat}}\right)$, stomatal conductance $\left(g_{\mathrm{s}}\right)$ and intercellular $\mathrm{CO}_{2}$ concentration $\left(C_{\mathrm{i}}\right)$. When gas exchanges reached equilibrium, isoprene samples were collected through 100-mg TenaxTA glass tubes (Thermal Desorption Tubes, Mesh 60/80, Gerstel, Germany) by means of a vacuum pump (GS1, Gerstel, Germany) at the rate of $200 \mathrm{~mL} \mathrm{~min}^{-1}$ for $20 \mathrm{~min}$, as explained in Yuan et al. (2016). Using a Li-Cor device for isoprene sampling scrubs $\mathrm{O}_{3}$ from the sample air, so that no reactions between $\mathrm{O}_{3}$ and Tenax may occur. At morning and afternoon of each sampling day, blank samples were also collected from ambient air. After sampling, tubes were immediately sealed with Teflon-coated caps, transported to the laboratory and stored in the refrigerator until analysis (less than three days from sampling to analysis).

Sample were analyzed by a thermal desorption system (TDS3; Gerstel, Germany) and GC/MS (GC 5890, MSD 5975; Agilent Technologies, Santa Clara, CA, USA). Samples were pre-focused by Cooled Injection System (CIS, Gerstel, Germany) by liquid nitrogen, and then desorbed and transferred to GC/MS by specific transfer line. The analysis was carried out by rising the column temperature from $40^{\circ} \mathrm{C}$ to $250^{\circ} \mathrm{C}$, at a rate of $5{ }^{\circ} \mathrm{C} \mathrm{min}^{-1}$ with helium as carrier gas. Isoprene was qualitative based on retention times and the NIST2.0 mass spectral database library (Agilent Technologies, Santa Clara, CA, USA), and then quantified using the pure liquid standards. Blank samples were analyzed synchronously and eventually subtracted from the samples emission results. Further details on those procedures are described in Yuan et al. (2016). Since the environmental conditions varied during sampling, the basic emission rates were standardized at $30{ }^{\circ} \mathrm{C}$ and $1000 \mu \mathrm{mol} \mathrm{m}{ }^{-2} \mathrm{~s}^{-1}$ PAR according to Guenther et al. (1993). Immediately, after isoprene sampling, leaf discs for chlorophyll analysis were sampled from the same leaves and treated with $2 \mathrm{ml}$ 95\% ethanol solution in the dark for about $72 \mathrm{~h}$ at $4{ }^{\circ} \mathrm{C}$ until completely fading. Chlorophyll $(a+b)$ content was measured by using the specific absorption coefficients $(664,649$ and $470 \mathrm{~nm}$ ) following Lichtenthaler (1989).

\subsection{Statistical analyses}

Normal distribution and homogeneity of variance were tested by the Kolmogorov-Smirnov one-sample D test and Levene's test, respectively. The single OTC was defined as statistical unit after averaging the two plants for each $\mathrm{N}$ level in each OTC. In order to test the effects of $\mathrm{O}_{3}, \mathrm{~N}$ and their interactions, the data of each dependent variable was subjected to analysis of variance by Tukey's Honestly Significant Difference (HSD) test with Mixed Linear Model using JMP software (SAS Institute, USA). We applied the analysis of covariance (ANCOVA) to check the difference in the slope of regression lines between isoprene emission and photosynthetic parameters by using SPSS18.0 (SPSS 18.0, Chicago, IL, USA). Results were considered significant when $P<0.05$. Data shown in figures are means $\pm \mathrm{SD}$ ( $\mathrm{n}=3$ OTCs).

\section{Results}

\subsection{Photosynthetic parameters}

Both $\mathrm{O}_{3}$ and $\mathrm{N}$ significantly affected $A_{\text {sat }}$ (Table 2). Relative to $\mathrm{CF}, A_{\text {sat }}$ significantly decreased by $29.2 \%$ in $\mathrm{NF}$ and $67.5 \%$ in $\mathrm{E}-\mathrm{O}_{3}$, when the effects were averaged across all the $\mathrm{N}$ treatments (Fig. 1a). Effects of $\mathrm{O}_{3}$ were also significant in the individual $\mathrm{N}$ treatments. Relative to N0, $A_{\text {sat }}$ significantly increased by $16.2 \%$ in N50 and $19.3 \%$ in N100, when the effects were averaged across all the $\mathrm{O}_{3}$ treatments (Fig. 1a). When the $\mathrm{N}$ effect was analyzed for any $\mathrm{O}_{3}$ treatment, the effect was statistically significant only in NF. This is why the $\mathrm{O}_{3} \times \mathrm{N}$ interaction was significant, i.e. $\mathrm{N}$ did not affect $A_{\text {sat }}$ in both $\mathrm{CF}$ and $\mathrm{E}-\mathrm{O}_{3}$ relative to NO, but significantly increased $A_{\text {sat }}$ in NF by $24.1 \%$ and $43.8 \%$ in N50 and N100, respectively.

Ozone significantly reduced $g_{s}$ while $\mathrm{N}$ did not affect it (Table 2). Compared to $\mathrm{CF}$, NF slightly decreased $g_{\mathrm{s}}$ by $12.4 \%$ and $\mathrm{E}-\mathrm{O}_{3}$ significantly reduced $g_{\mathrm{s}}$ by $18.3 \%$ when averaged across all $\mathrm{N}$ treatments (Fig. $1 \mathrm{~b}$ ), while $\mathrm{N}$ did not induce any significant difference when averaged across all the $\mathrm{O}_{3}$ treatments. Also the $\mathrm{O}_{3}$ and $\mathrm{N}$ interaction was not significant.

Both $\mathrm{O}_{3}$ and $\mathrm{N}$ had significant effects on $C_{\mathrm{i}}$ (Table 2). Relative to $\mathrm{CF}, C_{\mathrm{i}}$ was slightly increased by $4.1 \%$ in NF and significantly increased by $12.4 \%$ in $\mathrm{E}-\mathrm{O}_{3}$, when averaged across all $\mathrm{N}$ treatments (Fig. 1c). Relative to N0, $C_{\mathrm{i}}$ increased by $1.5 \%$ in N50 and significantly decreased by $4.8 \%$ in N100 when averaged across all $\mathrm{O}_{3}$ treatments.

The responses of chlorophyll content $(\mathrm{Chl})$ to $\mathrm{O}_{3}$ and $\mathrm{N}$ were similar to those of $A_{\text {sat }}$ (Table 2, Fig. 1a, d). Relative to CF, Chl slightly decreased by $3.1 \%$ in NF and significantly decreased by $32.4 \%$ in $\mathrm{E}-\mathrm{O}_{3}$ (Fig. 1d), when averaged across all the N treatments. Relative to N0, Chl significantly increased by $29.6 \%$ in N50 and $43.9 \%$ in N100, when averaged across all the $\mathrm{O}_{3}$ treatments (Fig. 1d). Different from $A_{\text {sat, }}$, however, Chl did not show a significant interaction between $\mathrm{O}_{3}$ and $\mathrm{N}$.

\subsection{Isoprene emission}

Both $\mathrm{O}_{3}$ and $\mathrm{N}$ significantly affected isoprene emission (Table 2, Fig. 2). Relative to $\mathrm{CF}$, isoprene emission significantly decreased by

Table 2

Results of ANOVA ( $P$ values) for the individual effects and interactions of $\mathrm{O}_{3}$ (CF, charcoalfiltered ambient air, $\mathrm{NF}$, non-filtered ambient air and $\mathrm{E}-\mathrm{O}_{3}$, elevated $\mathrm{O}_{3}$ ) and Nitrogen (NO $0 \mathrm{~kg} \mathrm{~N} \mathrm{ha}^{-1}$ year $^{-1}$, N50, $50 \mathrm{~kg} \mathrm{~N} \mathrm{ha}^{-1}$ year $^{-1}$ and N100, $100 \mathrm{~kg} \mathrm{~N} \mathrm{ha}^{-1}$ year $^{-1}$ ) on lightsaturated photosynthesis $\left(A_{\text {sat }}\right)$, stomatal conductance $\left(g_{\mathrm{s}}\right)$, intercellular $\mathrm{CO}_{2}$ concentration $\left(C_{\mathrm{i}}\right)$, chlorophyll $(a+b)$ content $(\mathrm{Chl})$, and isoprene emission. Statistically significant effects $(P<0.05)$ are marked in bold.

\begin{tabular}{llll}
\hline & Ozone $\left(\mathrm{O}_{3}\right)$ & Nitrogen $(\mathrm{N})$ & $\mathrm{O}_{3} \times \mathrm{N}$ \\
\hline$A_{\text {sat }}$ & $<\mathbf{0 . 0 0 0 1}$ & $\mathbf{0 . 0 0 0 3}$ & $\mathbf{0 . 0 2 6 0}$ \\
$g_{s}$ & $\mathbf{0 . 0 1 7 4}$ & 0.4612 & 0.1577 \\
$\mathrm{Ci}$ & $<\mathbf{0 . 0 0 0 1}$ & $\mathbf{0 . 0 0 8 6}$ & 0.6847 \\
$\mathrm{Chl}$ & $<\mathbf{0 . 0 0 0 1}$ & $<\mathbf{0 . 0 0 0 1}$ & 0.2390 \\
Isoprene emission & $<\mathbf{0 . 0 0 0 1}$ & $\mathbf{0 . 0 0 0 2}$ & 0.1200 \\
\hline
\end{tabular}



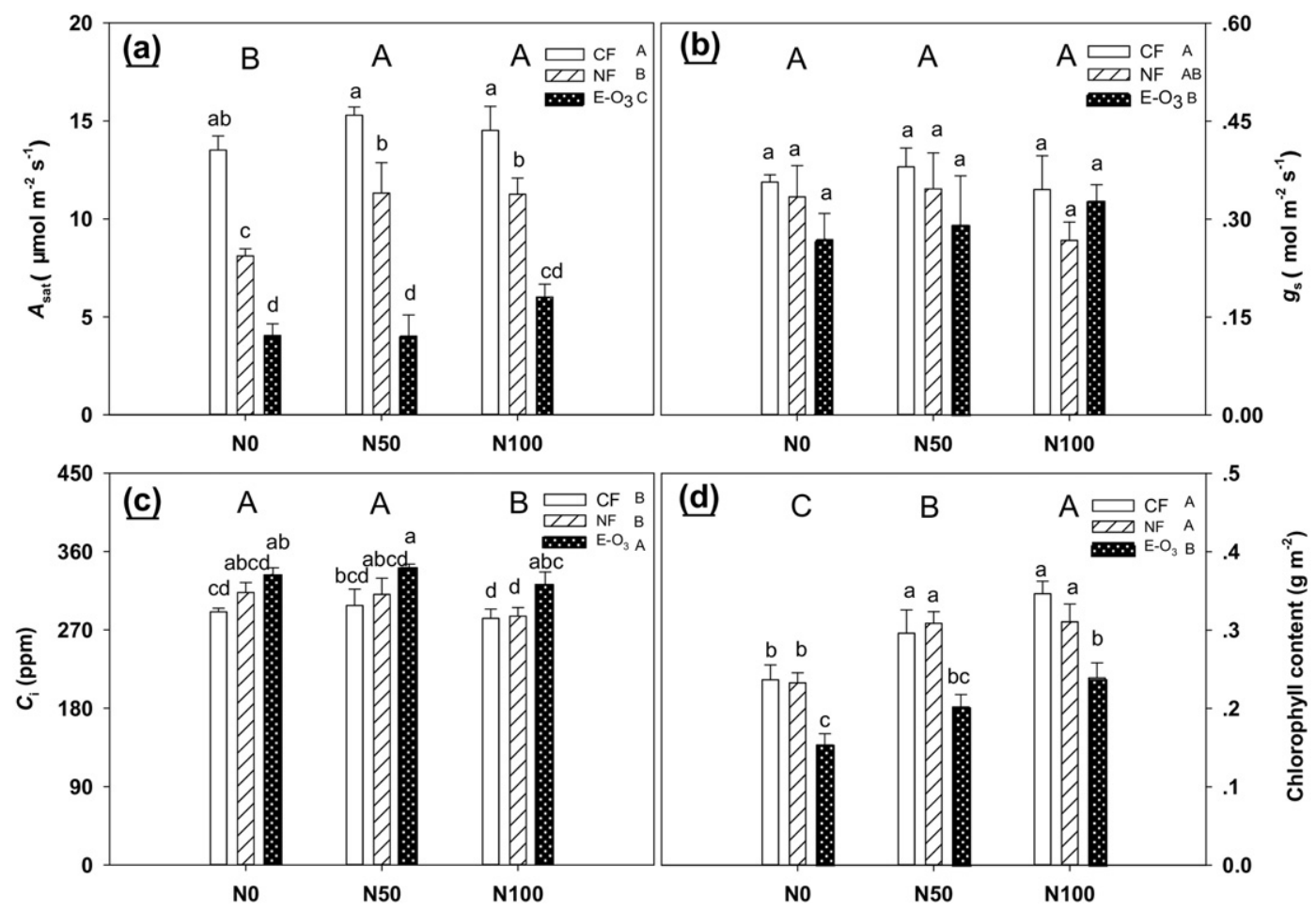

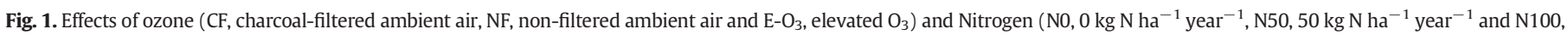

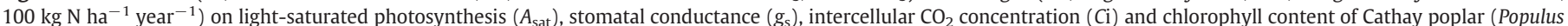

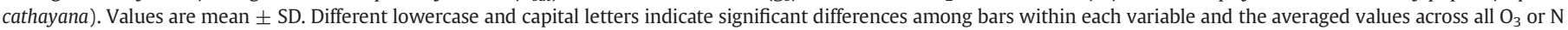
treatments, respectively (Tukey test, $P<0.05, \mathrm{n}=3$ OTCs).

$11.5 \%$ in $\mathrm{NF}$ and $57.9 \%$ in $\mathrm{E}_{-} \mathrm{O}_{3}$ when averaged across all the $\mathrm{N}$ treatments. Relative to N0, isoprene emission significantly increased by $19.6 \%$ in $\mathrm{N} 50$ and $33.4 \%$ in $\mathrm{N} 100$, when averaged across all the $\mathrm{O}_{3}$ treatments (Fig. 2). No significant interaction was observed.

\subsection{Correlation between isoprene emission and photosynthetic parameters}

A significant positive linear correlation was found between isoprene emission and $A_{\text {sat }}$ or Chl (Fig. 3a, d), while isoprene emission did not vary significantly with $g_{\mathrm{s}}$ (Fig. $3 \mathrm{~b}$ ) and decreased with increasing $C_{\mathrm{i}}$ (Fig. 3c). ANCOVA results did not show significant differences in the slope of the regression lines for the individual $\mathrm{O}_{3}$ or $\mathrm{N}$ treatments (not shown).

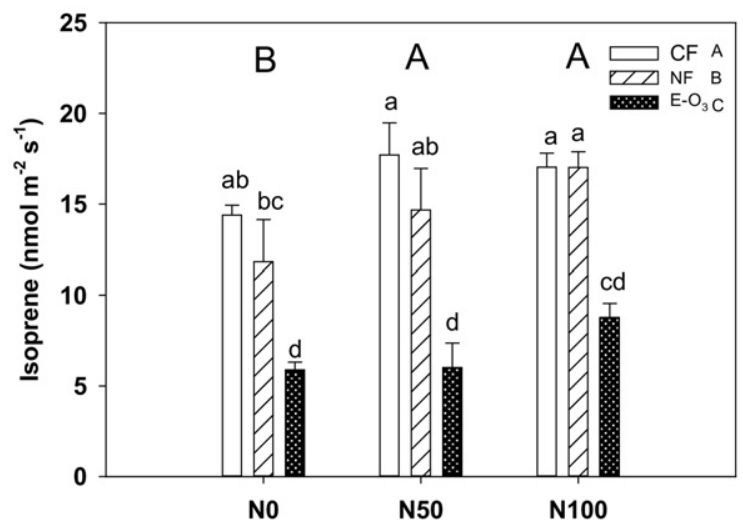

Fig. 2. Effects of ozone ( $\mathrm{CF}$, charcoal-filtered ambient air, NF, non-filtered ambient air and $\mathrm{E}_{-} \mathrm{O}_{3}$, elevated $\mathrm{O}_{3}$ ) and Nitrogen ( $\mathrm{N} 0,0 \mathrm{~kg} \mathrm{~N} \mathrm{ha}^{-1}$ year $^{-1}, \mathrm{~N} 50,50 \mathrm{~kg} \mathrm{~N} \mathrm{ha}^{-1}$ year $^{-1}$ and $\mathrm{N} 100,100 \mathrm{~kg} \mathrm{~N} \mathrm{ha}^{-1}$ year $^{-1}$ ) on standardized isoprene emission from Cathay poplar (Populus cathayana) leaves. Values are mean \pm SD. Different lowercase and capital letters indicate significant differences among bars within each variable and the averaged values across all $\mathrm{O}_{3}$ or $\mathrm{N}$ treatments, respectively (Tukey test, $P<0.05, \mathrm{n}=3$ OTCs).
Isoprene emission significantly decreased with increasing AOT40 for all $\mathrm{N}$ treatments with no significant difference among the slopes of the relationships in any $\mathrm{N}$ level (Fig. 4 ).

Consistent with isoprene, $A_{\text {sat }}, g_{\mathrm{s}}$ and Chl significantly decreased with increasing AOT40 for all $\mathrm{N}$ treatments with no significant difference among the slopes of these relationships (Fig. 5a, b, d), while $C_{\mathrm{i}}$ significantly increased with increasing AOT40 for all $\mathrm{N}$ treatments (Fig. $5 \mathrm{c}$ ).

\section{Discussion}

The results presented here extend our understanding of the interactions between $\mathrm{O}_{3}, \mathrm{~N}$ and isoprene emission from plants. So far, the combined effects of varying $\mathrm{O}_{3}$ and $\mathrm{N}$ levels have been investigated only on monoterpene or sesquiterpene emission (Blanch et al., 2007; Carriero et al., 2016; Llusià et al., 2014; Wang et al., 2012). Similar to P. alba (Fares et al., 2006), P. nigra (Fares et al., 2010) and hybrid poplar ( $P$. deltoides $c v .55 / 56 \times P$. deltoides $c v$. Imperial) (Yuan et al., 2016), Cathay poplar is a significant isoprene emitter.

\subsection{Effect of Ozone}

Relative to other $\mathrm{O}_{3}$ fumigation experiments (Bhatia et al., 2013; Booker et al., 2007; Tomer et al., 2015), the average $\mathrm{O}_{3}$ concentration in NF was very high in our study (Table 1 ), thus indicating that the suburban areas of Beijing had a very high ambient $\mathrm{O}_{3}$ concentration during the daytime of summer season. With the rapid industrialization and urbanization, high daily mean ambient $\mathrm{O}_{3}$ concentrations ( $>70 \mathrm{ppb}$ ) have been frequently observed during summer days in Beijing in recent years (Xin et al., 2016; Yuan et al., 2015). Therefore, an average daytime $\mathrm{O}_{3}$ concentration of $80.3 \mathrm{ppb}$ in $\mathrm{E}^{-\mathrm{O}_{3}}$ is a realistic level. AOT40 values in $\mathrm{NF}$ and $\mathrm{E}-\mathrm{O}_{3}$ exceeded the $\mathrm{O}_{3}$ critical level for forest protection ( 5 ppm h across six months, CLRTAP, 2015) and for Chinese poplar protection (12 ppm h, Hu et al., 2015). As expected, $\mathrm{O}_{3}$ in NF caused typical symptoms on Cathy poplar leaves especially under no $\mathrm{N}$ fertilization, 

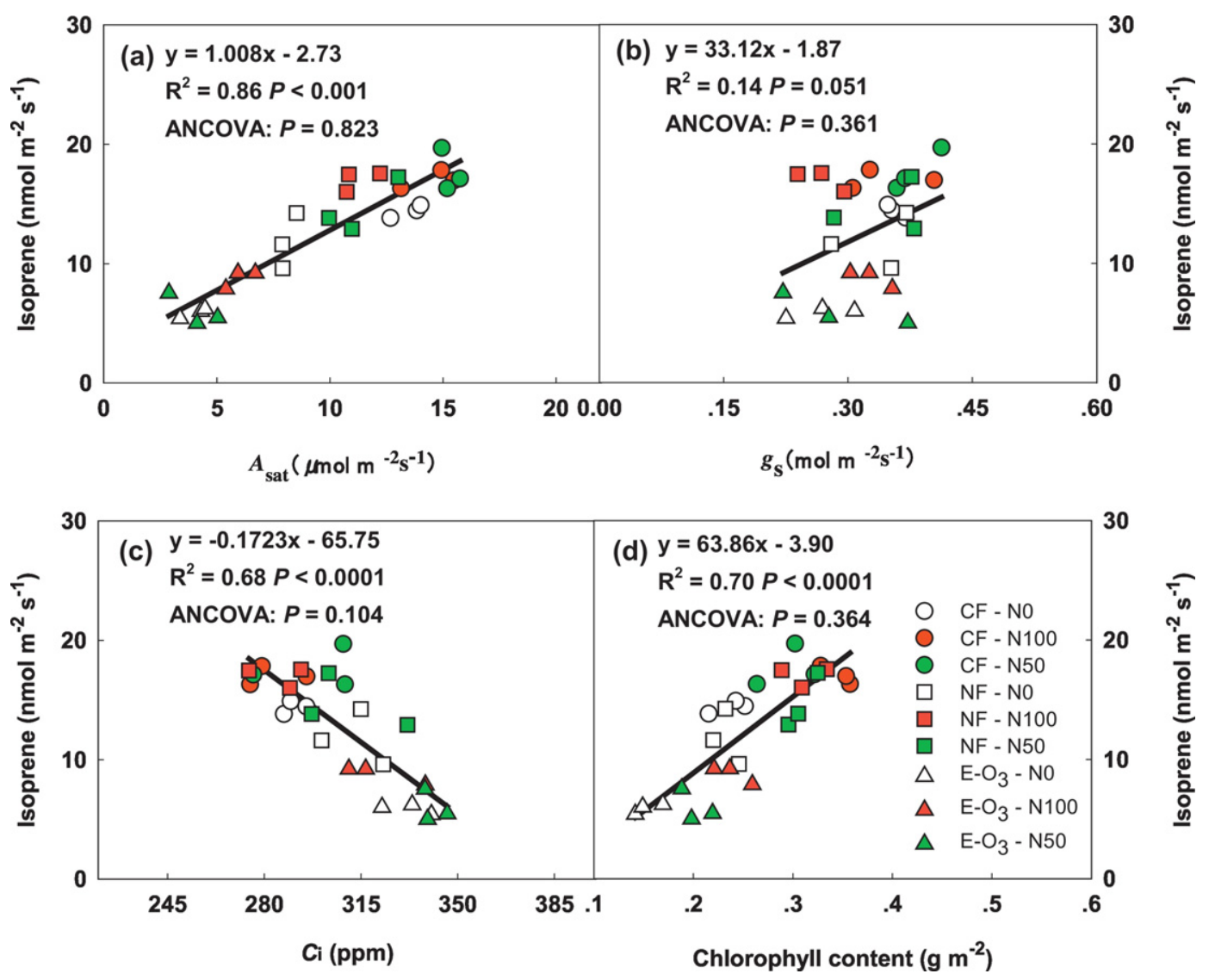

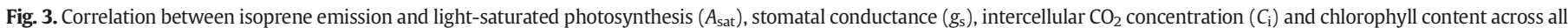

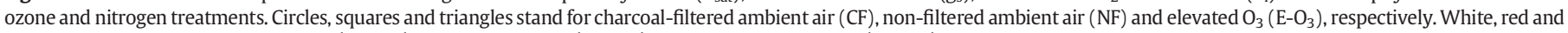

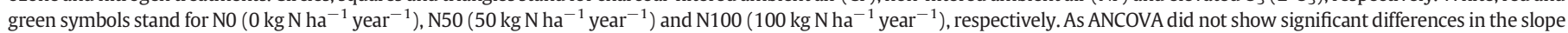
of the regression lines for the individual $\mathrm{O}_{3}$ or $\mathrm{N}$ treatments, one single line is shown.

and significant $\mathrm{O}_{3}$ visible injuries in $\mathrm{E}_{-} \mathrm{O}_{3}$ treatment in spite of $\mathrm{N}$ fertilization (data not show), thus confirming that $P$. cathayana is a very sensitive species to $\mathrm{O}_{3}$ (Xin et al., 2016).

An $\mathrm{O}_{3}$-induced reduction in $g_{\mathrm{s}}$ was observed in our study (Table 2 , Fig.1b), consistently with a previous review by Wittig et al. (2007), who indicated that decreased $g_{\mathrm{s}}$ by $\mathrm{O}_{3}$ is a universal phenomenon in

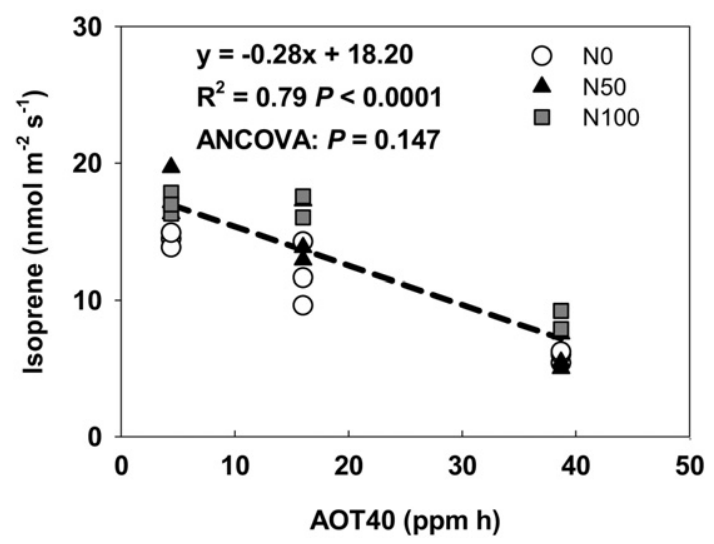

Fig. 4. Isoprene emission as a function of AOT40 ( $\mathrm{ppm} \mathrm{h})$. Circles, triangles and squares stand for N0 $\left(0 \mathrm{~kg} \mathrm{~N} \mathrm{ha}{ }^{-1}\right.$ year $\left.^{-1}\right), \mathrm{N} 50\left(50 \mathrm{~kg} \mathrm{~N} \mathrm{ha}^{-1} \mathrm{year}^{-1}\right)$ and N100 (100 kg N ha ${ }^{-1}$ year $^{-1}$ ), respectively. As ANCOVA did not show significant differences in the slope of the regression lines for the individual $\mathrm{N}$ treatments, one single dotted line is shown. trees, suggesting that stomatal closure was linked with the safeguard mechanism of plants against negative $\mathrm{O}_{3}$ stress (Reich, 1987). On the other hand, stomatal closure is considered to be indirect effect of $\mathrm{O}_{3}$, caused by increased $\mathrm{Ci}$ as photosynthesis is impaired (Yamaguchi et al., 2007). Our result was consistent with this theory (Table 2, Fig. $1 \mathrm{~b}, \mathrm{c}$ ), then resulting in a reduced photosynthetic rate (Table 2, Fig. 1a).

Although the effects of $\mathrm{O}_{3}$ on isoprenoid emissions of plants have been suggested to vary with $\mathrm{O}_{3}$ concentrations, duration of exposure, plant species and environmental conditions (Loreto and Schnitzler, 2010; Pinto et al., 2010), this study indicated that an average daytime $\mathrm{O}_{3}$ concentration higher than $80 \mathrm{ppb}$ (Table 1 , Figs 1,2 ) significantly decreased isoprene emission, together with a significant decrease in $A_{\text {sat }}$ and $\mathrm{Chl}$. The inhibition of isoprene emission at elevated $\mathrm{O}_{3}$ occurred in several studies, with long term and high dose of $\mathrm{O}_{3}$ exposure (Calfapietra et al., 2008; Cojocariu et al., 2005; Ryan et al., 2009; Yuan et al., 2016). When high $\mathrm{O}_{3}$ concentration impairs the photosynthetic process, the biosynthetic formation of isoprene is decreased (Sharkey and Loreto, 1993).

\subsection{Effect of nitrogen}

The medium and high $\mathrm{N}$ load used in our study ( $50 \mathrm{~kg} \mathrm{~N}^{-1} \mathrm{year}^{-1}$ and $100 \mathrm{~kg} \mathrm{~N} \mathrm{ha}^{-1}$ year $^{-1}$, respectively) was higher than the peak value of $\mathrm{N}$ deposition in Europe ( 20.0 to $28.1 \mathrm{~kg} \mathrm{~N} \mathrm{ha}^{-1} \mathrm{year}^{-1}$ ), South Asia (20.0 to $30.6 \mathrm{~kg} \mathrm{~N} \mathrm{ha}^{-1}$ year $^{-1}$ ), USA and Canada (10.0 to $20 \mathrm{~kg} \mathrm{~N}^{-1}$ year $^{-1}$ ) (Vet et al., 2014; Zhu et al., 2015). However, these $\mathrm{N}$ deposition levels are realistic in China, especially in North 

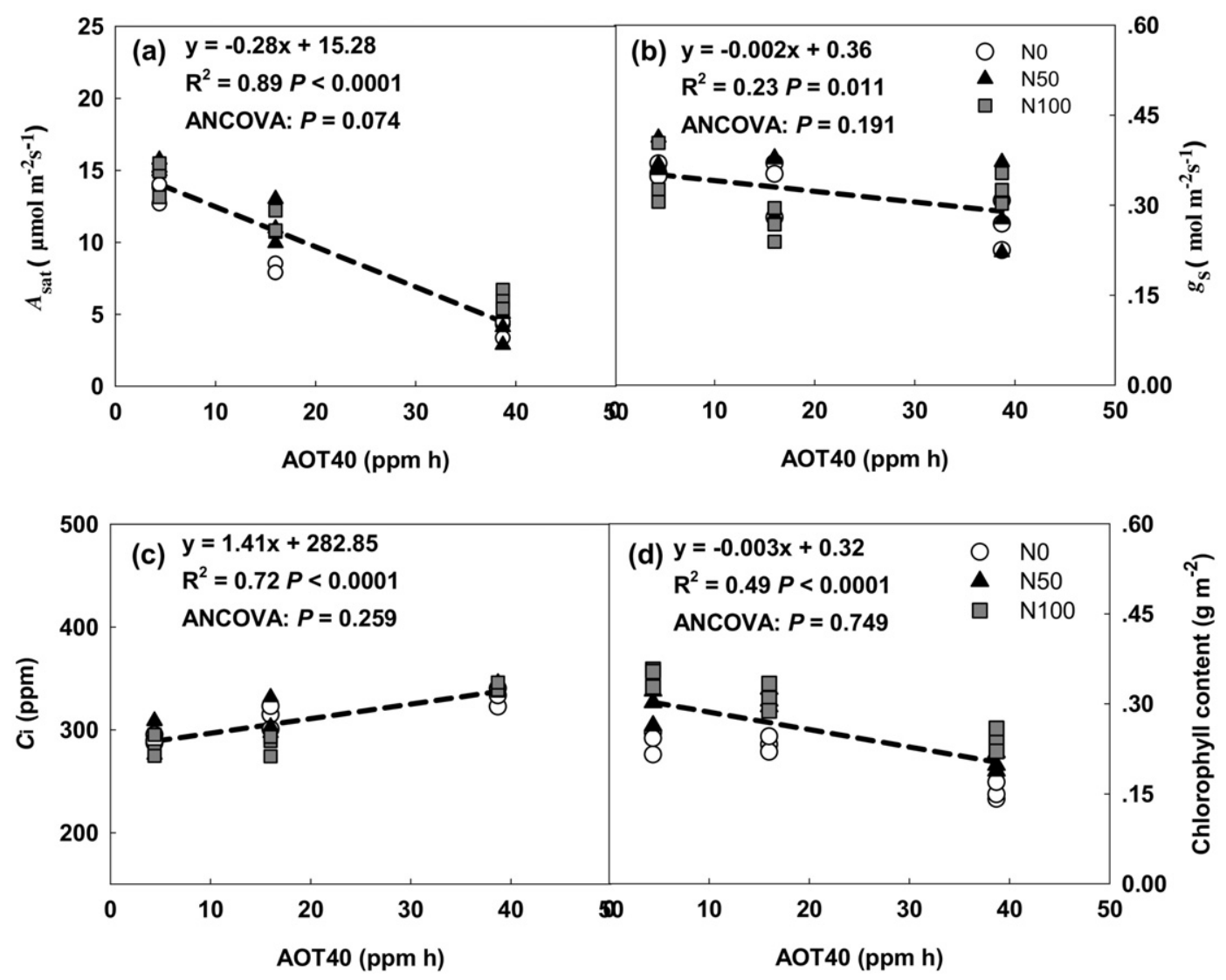

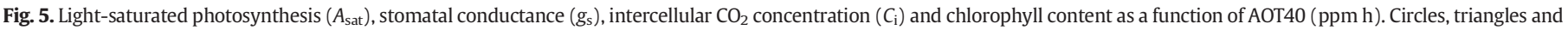

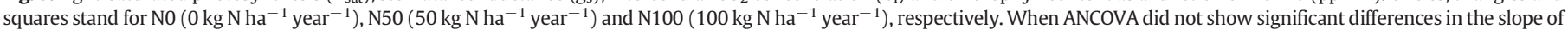
the regression lines for the individual $\mathrm{N}$ treatments, one single dotted line is shown.

China Plain with over-fertilization of agricultural production (Liu et al., 2011). Liu et al. (2006) reported yearly bulk N deposition (i.e. mostly wet) up to $30 \mathrm{~kg} \mathrm{~N} \mathrm{ha}^{-1}$ year $^{-1}$ (only inorganic N) in the Beijing area of China, reaching $83.3 \mathrm{~kg} \mathrm{~N}^{-1}$ year $^{-1}$ if both inorganic and organic $\mathrm{N}$ were included. Such high $\mathrm{N}$ depositions are expected to further rise in the future due to rising combustion of fossil fuel and to increasing production and application of nitrogenous fertilizers (Liu et al., 2011, 2013).

Unlike $\mathrm{O}_{3}$ stress, enhanced $\mathrm{N}$ availability significantly increased isoprene emission, $A_{\text {sat }}$, and Chl (Table 2, Figs. 1, 2). Although the current result is consistent with studies, in which elevated $\mathrm{N}$ in the soil is highly correlated with $A_{\text {sat }}$ and Chl, e.g. in Larix (Li et al., 2016) and Brassica species (Seepaul et al., 2016), other studies reported that modest $\mathrm{N}$ load (40 $\mathrm{kg} \mathrm{N} \mathrm{ha}^{-1}$ ) did not affect the photosynthetic rates and reduced the emission of terpenes in 0 . compressus and T. striatum, compared to no N load (Llusià et al., 2014). Blanch et al. (2007) also found that a high $\mathrm{N}$ load ( $250 \mathrm{~kg} \mathrm{~N} \mathrm{ha}^{-1}$ ) reduced the emission of terpenoids from $P$. halepensis by $38 \%$. Those reductions may be explained by the carbon/nutrient balance hypotheses ( $\mathrm{CNBH}$ ), i.e. higher nutrient availability would stimulate more carbon allocation to plant growth rather than to carbon-based secondary compounds such as terpenoids (Peñuelas and Estiarte, 1998). However, in our study, the expected decline did not occur, even at high $\mathrm{N}$ load. Nitrogen could promote isoprene emission by promoting leaf photosynthesis and thus improving energy and carbon availability for isoprene synthesis (Ormeño and Fernandez, 2012). Consistent with this theory, isoprene emission increased with increasing $A_{\text {sat }}$ in this study (Fig. 3a). Peñuelas and Staudt (2010) reviewed the limited knowledge on the effects of $\mathrm{N}$ on isoprenoids and found that positive effects were more frequent for isoprene than for monoterpenes (Harley et al., 1994; Litvak et al., 1996). For monoterpenes, mostly negative (Blanch et al., 2007; Carriero et al., 2016; Llusià et al., 2014) or no effects (Kainulainen et al., 2000) were reported.

\subsection{Interaction of ozone and nitrogen}

Only $A_{\text {sat }}$ showed a significant interaction between $\mathrm{O}_{3}$ and $\mathrm{N}$ as the adverse effect of elevated $\mathrm{O}_{3}$ was alleviated by higher soil $\mathrm{N}$ availability (Table 2, Fig.1a). A counteracting effect of $\mathrm{N}$ and $\mathrm{O}_{3}$ on $A_{\text {sat }}$ has been already reported for Picea abies Karst. (Lippert et al., 1996), Fagus crenata (Yamaguchi et al., 2007) and Cinnamomum camphora seedlings (Feng et al., 2011), although this effect depended on plant type, exposure levels and plant growth stage. However, the interaction of $\mathrm{O}_{3}$ exposure and $\mathrm{N}$ load on isoprene emission was not statistically significant in Cathay poplar (Table 2, Fig. 2). This is consistent with Llusià et al. (2014), who reported evident effects of individual $\mathrm{N}$ load or $\mathrm{O}_{3}$ exposure on terpene emission from $O$. compressus and $T$. striatum, while the combined effect was not significant. Such inconsistent response of $A_{\text {sat }}$ and isoprene emission suggests that isoprene emission is less sensitive to stressors than photosynthesis (Brilli et al., 2007; Seco et al., 2015).

Increase of isoprene emission was accompanied by an increase of $A_{\text {sat }}$ and Chl (Fig. 3a, d) instead of $g_{\text {s }}$ (Fig. 3b), confirming previous findings (Yuan et al., 2016). In contrast, isoprene emission decreased with increasing $C_{\mathrm{i}}$ (Fig. 3c), as expected under $\mathrm{O}_{3}$ stress (Yuan et al., 2016). Such change may have an indirect effect on isoprene emission by adjusting the allocation proportion of cytosolic phosphoenolpyruvate (PEP) between respiration and the process of synthesizing dimethylallyl diphosphate (DMADP) in chloroplast, which is the immediate precursor of isoprene formation (Rosenstiel et al., 2002; Brilli et al., 2007). When $C_{\mathrm{i}}$ increased under $\mathrm{O}_{3}$ stress, the chloroplastic import of PEP from respiratory processes towards DMADP formation is decreased, further limiting isoprene emission.

Interestingly, the regression lines between any photosynthetic parameter (but $A_{\text {sat }}$ ) and isoprene emission were not affected by either 
$\mathrm{O}_{3}$ or $\mathrm{N}$, and thus only one equation was provided. This suggests that $\mathrm{O}_{3}$ and $\mathrm{N}$ did not interact synergistically or antagonistically. An additive effect of the combined $\mathrm{O}_{3}$ exposure and $\mathrm{N}$ load on BVOC emission was also reported in a monoterpene-emitter tree species (B. pendula) (Carriero et al., 2016).

In order to test the long-term effects of $\mathrm{O}_{3}$ on isoprene emission at different $\mathrm{N}$ levels, we used AOT40 as a metric. Consistent with $A_{\mathrm{sat}}, g_{\mathrm{s}}$ and $\mathrm{Chl}$, isoprene decreased significantly with increasing AOT40 for all $\mathrm{N}$ treatments, with no significant effect of $\mathrm{N}$ on the slopes of these responses (Figs. 4, 5). However, Carriero et al. (2016) reported an opposite response, which described an increase of monoterpene emissions in Betula pendula seedlings with increasing AOT40. Such controversial responses to long-term $\mathrm{O}_{3}$ accumulation may result from differences in duration and intensity of $\mathrm{O}_{3}$ exposure, extent of $\mathrm{O}_{3}$ visible foliar injury, and BVOC type (Loreto and Schnitzler, 2010; Peñuelas and Staudt, 2010).

\section{Conclusions}

This is the first study that quantifies the combined effects of $\mathrm{O}_{3}$ exposure and $\mathrm{N}$ load on isoprene emission from plants. Our results pointed out that increasing $\mathrm{O}_{3}$ exposure decreased isoprene emission, in tandem with $A_{\text {sat }}$ and Chl, while $\mathrm{N}$ load increased isoprene emission still in tandem with $A_{\text {sat }}$ and Chl. The combined effects of $\mathrm{O}_{3}$ exposure and $\mathrm{N}$ load on isoprene emission were additive and did not interact significantly. These results will help a proper modeling of the interactive effects of these co-existing global change factors on plant physiology, future isoprene emission and atmospheric chemical processes.

\section{Acknowledgements}

This study was funded by the Hundred Talents Program, Chinese Academy of Sciences (CAS) and State Key Laboratory of Desert and Oasis Ecology, Xinjiang Institute of Ecology and Geography, CAS (G2015-0202), Key Research Program of Frontier Sciences, CAS (QYZDB-SSWDQC019), Chinese Academy of Sciences President's International Fellowship Initiative (PIFI) for Senior Scientists (2016VBA057) and CNRCAS bilateral agreement 'Ozone impacts on plant ecosystems in China and Italy' (2017-2019).

\section{References}

Ainsworth, E.A., Yendrek, C.R., Sitch, S., Collins, W.J., Emberson, L., 2012. The effects of tropospheric ozone on net primary productivity and implications for climate change. Annu. Rev. Plant Biol. 63, 637-661.

Bhatia, A., Kumar, V., Kumar, A., Tomer, R., Singh, B., Singh, S., 2013. Effect of elevated ozone and carbon dioxide interaction on growth and yield of maize. Maydica 58, 291-298.

Blanch, J.S., Peñuelas, J., Llusià, J., 2007. Sensitivity of terpene emissions to drought and fertilization in terpene-storing Pinus halepensis and non-storing Quercus ilex. Physiol. Plant. 131, 211-225.

Booker, F.L., Burkey, K.O., Pursley, W.A., Heagle, A.S., 2007. Elevated carbon dioxide and ozone effects on peanut. I. Gas-exchange, biomass, and leaf chemistry. Crop Sci. 47, 1475-1487.

Brilli, F., Barta, C., Fortunati, A., Lerdau, M., Loreto, F., Centritto, M., 2007. Response of isoprene emission and carbon metabolism to drought in white poplar (Populus alba) saplings. New Phytol. 175, 244-254.

Calfapietra, C., Scarascia Mugnozza, G. Karnosky, D. Loreto, F., Sharkey, T.D., 2008. Isoprene emission rates under elevated $\mathrm{CO}_{2}$ and $\mathrm{O}_{3}$ in two field-grown aspen clones differing in their sensitivity to $\mathrm{O}_{3}$. New Phytol. 179, 55-61.

Cardoso-Vilhena, J., Barnes, J., 2001. Does nitrogen supply affect the response of wheat (Triticum aestivum $\mathrm{cv}$. Hanno) to the combination of elevated $\mathrm{CO}_{2}$ and $\mathrm{O}_{3}$ ? J. Exp. Bot. 52, 1901-1911.

Carriero, G., Brunetti, C., Fares, S., Hayes, F., Hoshika, Y., Mills, G., Tattini, M., Paoletti, E., 2016. BVOC responses to realistic nitrogen fertilization and ozone exposure in silver birch. Environ. Pollut. 213, 988-995.

Claeys, M., Grahan, B., Vas, G., Wang, W., Vermeylen, R., Pashynska, V., Cafmeyer, J., Guyon, P., Andreae, M.O., Artaxo, P., Maenhaut, W., 2004. Formation of secondary organic aerosols through photooxidation of isoprene. Science 20, 1173-1176.

CLRTAR, 2015. Chapter 3: Mapping critical levels for vegetation. Manual on methodologies and criteria for modelling and mapping critical loads \& levels and air pollution effects, risks and trends. Manual on Methodologies and Criteria for Modelling and Mapping Critical Loads and Levels and Air Pollution Effects, Risks and Trends. United Nations Economic Commission for Europe (UNECE) Convention on Long-range Transboundary Air Pollution, Geneva (URL:http://www.icpmapping.org).
Cojocariu, C., Escher, P., Häberle, K.H., Matyssek, R., Rennenberg, H., Kreuzwieser, J., 2005. The effect of ozone on the emission of carbonyls from leaves of adult Fagus sylvatica. Plant Cell Environ. 28, 603-611.

Cooper, O.R., Parrish, D.D., Ziemke, J., Balashov, N.V., Cupeiro, M., Galbally, I.E., Gilge, S. Horowitz, L., Jensen, N.R., Lamarque, J.F., et al., 2014. Global distributon and trends of tropospheric ozone: an observation-based review. Elem. Sci. Anth. 2014, 2-29.

Cooper, O.R., Langford, A.O., Parrish, D.D., Fahey, D.W., 2015. Challenges of a lowered U.S ozone standard. Science 348 (6239), 1096-1097.

Dentener, F., Keating, T., Akimoto, H., 2010. Hemispheric Transport of Air Pollution 2010 Part A: Ozone and Particulate Matter. UN, New York, p. 278.

Ding, A.J., Wang, T., Thouret, V., Cammas, J.P., Nedéléc, P., 2008. Tropospheric ozoneclimatology over Beijing: analysis of aircraft data from the MOZAIC program. Atmos. Chem. Phys. 8, 1-13.

Fan, H.B., Liu, W.F., Li, Y.Y., Liao, Y.C., Yuan, Y.H., Xu, L., 2007. Tree growth and soil nutrients in response to nitrogen deposition in a subtropical Chinese fir plantation. Acta Ecol. Sin. 27, 4630-4642 (in Chinese).

Fares, S., Barta, C., Brilli, F., Centritto, M., Ederli, L., Ferranti, F., Pasqualini, S., Reale, L. Tricoli, D., Loreto, F., 2006. Impact of high ozone on isoprene emission, photosynthesis and histology of developing Populus alba leaves directly or indirectly exposed to the pollutant. Physiol. Plant. 128, 456-465.

Fares, S., Oksanen, E., Lännenpää, M., Julkunen-Tiitto, R., Loreto, F., 2010. Volatile emissions and phenolic compound concentrations along a vertical profile of Populus nigra leaves exposed to realistic ozone concentrations. Photosynth. Res. 104, 61-74.

Feng, Z.Z., Kobayashi, K., 2009. Assessing the impacts of current and future concentrations of surface ozone on crop yield with meta-analysis. Atmos. Environ. 43, 1510-1519.

Feng, Z.Z., Niu, J.F., Zhang, W.W., Wang, X.K., Yao, F.F., Tian, Y., 2011. Effects of ozone exposure on sub-tropical evergreen Cinnamomum camphora seedlings grown in different nitrogen loads. Trees 25, 617-625.

Feng, Z.Z., Sun, J.S., Wan, W.X., Hu, E.Z., Calatayud, V., 2014. Evidence of widespread ozone induced visible injury on plants in Beijing, China. Environ. Pollut. 193, 296-301.

Feng, Z.Z., Liu, X.J., Zhang, F.S., 2015. Air pollution affects food security in China: taking ozone as an example. Front. Agr. Sci. Eng. 2 (2), 152-158.

Filella, I., Primante, C., Llusi, J., Martín González, A.M., Seco, R., Farré-Armengol, G. Rodrigo, A., Bosch, J., Peñuelas, J., 2013. Floral advertisement scent in a changing plant-pollinators market. Sci. Rep. 3, 3434.

Galloway, J.N., Dentener, F.J., Capone, D.G., Boyer, E.W., Howarth, R.W., Seitzinger, S.P. Asner, G.P., Cleveland, C.C., Green, P.A., Holland, E.A., et al., 2004. Nitrogen cycles: past, present and future. Biogeochemistry 70, 153-226.

Guenther, A., Zimmerman, P.R., Harley, P.C., Monson, R.K., Fall, R., 1993. Isoprene and monoterpene emission rate variability-model evaluations and sensitivity analyses. J. Geophys. Res. 98 (D7), 12609-12617.

Guenther, A., Nicholas Hewitt, C., Erickson, D., Fall, R., Geron, C., Graedel, T., Harley, P. Klinger, L., Lerdau, M., Mckay, W.A., et al., 1995. A global model of natural volatile organic compound emissions. J. Geophys. Res. 100, 8873-8892.

Häikiö, E., Freiwald, V., Silfver, T., Beuker, E., Holopainen, T., Oksanen, E., 2007. Impacts of elevated ozone and nitrogen on growth and photosynthesis of European aspen (Populus tremula) and hybrid aspen (P. tremula $\times$ Populus tremuloides) clones. Can. J. For. Res. 37, 2326-2336.

Handley, T., Grulke, N.E., 2008. Interactive effects of $\mathrm{O}_{3}$ exposure on California black oak (Quercus kelloggii Newb.) seedlings with and without N amendment. Environ. Pollut. 156, 53-60.

Harley, P.C., Litvak, M.E., Sharkey, T.D., Monson, R.K., 1994. Isoprene emission from velve bean leaves-interactions among nitrogen availability, growth photon flux density, and leaf development. J. Plant Physiol. 105, 279-285.

Hartmann, D.L., Klein Tank, A.M.G., Rusticucci, M., 2013. Observations: atmosphere and surface. In: Stocker, T.F. (Ed.), Climate Change 2013: The Physical Science Basis. Contribution of Working Group I to the Fifth Assessment Report of the Intergovernmental Panel on Climate Change. Cambridge Univ. Press, Cambridge, UK, and New York, USA, pp. 159-254.

Holopainen, J.K., Gershenzon, J., 2010. Multiple stress factors and the emission of plant VOCs. Trends Plant Sci. 15 (3), 176-184.

Hu, E.Z., Gao, F., Xin, Y., Jia, H.X., Li, K.H., Hu, J.J., Feng, Z.Z., 2015. Concentration- and fluxbased ozone dose-response relationships for five poplar clones grown in North China. Environ. Pollut 207, 21-30.

Huang, J., Liu, H., Crawford, J.H., Chan, C., Considine, D.B., Zhang, Y., Zheng, X., Zhao, C. Thouret, V., et al., 2015. Origin of springtime ozone enhancements in the lower troposphere. Atmos. Chem. Phys. 15, 5161-5179.

Kainulainen, P., Utriainen, J., Holopainen, J.K., Oksanen, J., Holopainen, T., 2000. Influence of elevated ozone and limited nitrogen availability on conifer seedlings in an open-air fumigation system: effects on growth, nutrient content, mycorrhiza needle ultrastructure, starch and secondary compounds. Glob. Chang. Biol. 6 345-355.

Kesselmeier, J., Staudt, M., 1999. Biogenic volatile organic compounds (VOC): an overview on emission, physiology and ecology. J. Atmos. Chem. 33, 23-88.

Li, J.Y., Guo, Q.X., Zhang, Z.X., Korpelainen, H., Li, C.Y., 2016. Effects of nitrogen and phosphorus supply on growth and physiological traits of two Larix species. Environ. Exp. Bot. 130, 206-215.

Lichtenthaler, H.K., 1989. Chlorophylls and carotenoids: pigments of photosynthetic biomembranes. Methods Enzymol. 148, 350-382.

Lippert, M., Häberle, K.H., Steiner, K., Payer, H.D., Rehfuess, K.E., 1996. Interactive effects of elevated $\mathrm{CO}_{2}$ and $\mathrm{O}_{3}$ on photosynthesis and biomass production of clonal 5-year-old Norway spruce (Picea abies L. Karst.) under different nitrogen nutrition and irrigation treatments. Trees 10 (6), 382-392 (1996).

Litvak, M.E., Loreto, F., Harley, P.C., Sharkey, T.D., Monson, R.K., 1996. Plant Cell Environ. $19,549-559$.

Liu, X.J., Ju, X.T., Zhang, Y., He, C.E., Kopsch, J., Zhang, F.S., 2006. Nitrogen deposition in agroecosystems in the Beijing area. Agric. Ecosyst. Environ. 113, 370-377.

Liu, X.J., Duan, L., Mo, J.M., Du, E.Z., Shen, J.L., Lu, X.K., Zhang, Y., Zhou, X.B., He, C., Zhang, F.S., 2011. Nitrogen deposition and its ecological impact in China: an overview. Environ. Pollut 159 (10), 2251-2264. 
Liu, X.Y., Zhang, Y., Han, W.X., Tang, A.H., Shen, J.L., Cui, Z.L., Vitousek, P., Erisman, J.W Goulding, K., Christie, P., et al., 2013. Enhanced nitrogen deposition over China. Nature 494, 459-463.

Llusià, J., Peñuelas, J., Gimeno, B.S., 2002. Seasonal and species-specific response of VOC emissions by Mediterranean woody plant to elevated ozone concentrations. Atmos. Environ. 36, 3931-3938.

Llusià, J., Bermejo-Bermejo, V., Calvete-Sogo, H., Penuelas, J., 2014. Decreased rates of terpene emissions in Ornithopus compressus L. and Trifolium striatum L. by ozone exposure and nitrogen fertilization. Environ. Pollut. 194, 69-77.

Loreto, F., Schnitzler, J.P., 2010. Abiotic stresses and induced BVOCs: a review. Trends Plant Sci. 15, 154-166.

Ormeño, E., Fernandez, C., 2012. Effect of soil nutrient on production and diversity of volatile terpenoids from plants. Curr. Bioact. Compd. 8, 71-79.

Paasonen, P., Asmi, A., Petäjä, T., Kajos, M.K., Aijälä, M., Junninen, H., Holst, T., Abbatt, J.P.D., Arneth, A., Birmili, W., et al., 2013. Warming-induced increase in aerosol number concentration likely to moderate climate change. Nat. Geosci. 6, 438-442.

Paoletti, E., De Marco, A., Beddows, D.C.S., Harrison, R.M., Manning, W.J., 2014. Ozone levels in European and USA cities are increasing more than at rural sites, while peak values are decreasing. Environ. Pollut. 192, 295-299.

Peñuelas, J., Estiarte, M., 1998. Can elevated $\mathrm{CO}_{2}$ affect secondary metabolism and ecosystem function? Trees 13, 20-24.

Peñuelas, J., Staudt, M., 2010. BVOCs and global change. Trends Plant Sci. 15, 133-144

Pinto, D.M., Blande, J.D., Souza, S.R., Nerg, A.M., Holopainen, J.K., 2010. Plant volatile organic compounds (VOCs) in ozone $\left(\mathrm{O}_{3}\right)$ polluted atmospheres: the ecological effects. J. Chem. Ecol. 36, 22-34

Reich, P.B., 1987. Quantifying plant response to ozone: a unifying theory. Tree Physiol. 3, 63-91.

Revell, L.E., Tummon, F., Stenke, A., Sukhodolov, T., Coulon, A., Rozanov, E., Garny, H., Grewe, V., Peter, T., 2015. Drivers of the tropospheric ozone budget throughout the 21 st century under the medium-high climate scenario RCP 6.0. Atmos. Chem. Phys. $15,5887-5902$

Rosenstiel, T.N., Fisher, A.J., Fall, R., Monson, R.K., 2002. Differential accumulation of dimethyallyl diphosphate in leaves and needles of isoprene and methylbuthenolemitting and non-emitting species. Plant Physiol. 129, 1276-1284.

Ryan, A., Cojocariu, C., Possell, M., Davies, W.J., Hewitt, C.N., 2009. Defining hybrid poplar (Populus deltoides $\times$ Populus trichocarpa) tolerance to ozone: identifying key parameters. Plant Cell Environ. 32, 31-45.

Seco, R., Karl, T., Guenther, A., Hosman, K.P., Pallardy, S.G., Gu, L.H., Geron, C., Harley, P. Kim, S., 2015. Ecosystem-scale volatile organic compound fluxes during an extreme drought in a broadleaf temperate forest of the Missouri Ozarks (central USA). Glob. Chang. Biol. 21, 3657-3674.

Seepaul, R., George, S., Wright, D.L., 2016. Comparative response of Brassica carinata and $B$ napus vegetative growth, development and photosynthesis to nitrogen nutrition. Ind. Crop. Prod. 94, 872-883.

Sharkey, T.D., Loreto, F., 1993. Water stress, temperature, and PFD effects on the capacity for isoprene emission and photosynthesis of kudzu leaves. Oecologia 95, 328-333.

Sharkey, T.D., Monson, R.K., 2017. Isoprene research - 60 years later, the biology is still enigmatic. Plant Cell Environ. http://dx.doi.org/10.1111/pce.12930.
Sharkey, T.D., Yeh, S., 2001. Isoprene emission from plants. Annu. Rev. Plant Physiol. Mol. Biol. 52, 407-436.

Sicard, P., Serra, R., Rossello, P., 2016. Spatiotemporal trends in ground-level ozone concentrations and metrics in France over the time period 1999-2012. Environ. Res. $149,122-144$.

Sutton, M.A., M., K.E., Sheppard, L.J., Sverdrup, H., Haeuber, R., Hicks, W.K., 2014. Chapter 14, factors affecting nitrogen deposition impacts on biodiversity: an overview. Nitrogen Deposition, Critical Loads and Biodiversity. Springer, Berlin, Germany, p. 127.

Tomer, R., Bhatia, A., Kumar, V., Kumar, A., Singh, R., Singh, B., Singh, S.D., 2015. Impact of elevated ozone on growth, yield and nutritional quality of two wheat species in Northern India. Aerosol Air Qual. Res. 15, 329-340.

Vet, R., Artz, R.S., Carou, S., 2014. A global assessment of precipitation chemistry and deposition of sulfur, nitrogen, sea salt, base cations, organic acids, acidity and $\mathrm{pH}$, and phosphorus. Atmos. Environ. 93, 3-100.

Wang, T., Wei, X.L., Ding, A.J., Poon, C.N., Lam, K.S., Li, Y.S., Chan, L.Y., Anson, M., 2009. Increasing surface ozone concentrations in the background atmosphere of Southern China, 1994-2007. Atmos. Chem. Phys. 9, 6217-6227.

Wang, HJ., Xia, J.Y., Mu, Y.J. Nie, L., Han, X.G., Wan, S.Q. 2012. BVOCs emission in a semiarid grassland under climate warming and nitrogen deposition. Atmos. Chem. Phys. $12,3809-3819$

Wittig, V.E., Ainsworth, E.A., Long, S.P., 2007. To what extent do current and projected increases in surface ozone affect photosynthesis and stomatal conductance of trees? A meta-analytic review of the last 3 decades of experiments. Plant Cell Environ. 30, $1150-1162$.

Wittig, V.E., Ainsworth, E.A., Naidu, S.L., Karnosky, D.F., Long, S.P., 2009. Quantifying the impact of current and future tropospheric ozone on tree biomass, growth, physiology and biochemistry: a quantitative meta-analysis. Glob. Chang. Biol. 15, 396-424.

Xin, Y., Yuan, X.Y., Shang, B., Manning, W.J., Yang, A.Z., Wang, Y.N., Feng, Z.Z., 2016. Moderate drought did not affect the effectiveness of ethylenediurea (EDU) in protecting Populus cathayana from ambient ozone. Sci. Total Environ. 569, 1536-1544.

Xu, M., Zhou, X., Piao, C., 2009. Populus cultivation-clones in different cultivated area and its diseases in China. For. Res. 22, 705-714 (in Chinese).

Yamaguchi, M., Watanabe, M., Matsuo, N., Naba, J., Funada, R., Fukami, M., Matsumura, H., Kohno, Y., Izuta, T., 2007. Effects of nitrogen supply on the sensitivity to $\mathrm{O}_{3}$ of growth and photosynthesis of Japanese Beech (Fagus crenata) Seedlings. Water Air Soil Pollut. 7, 131-136.

Yuan, X.Y., Calatayud, V., Jiang, L.J., Manning, W.J., Hayes, F., Tian, Y., Feng, Z.Z., 2015. Assessing the effects of ambient ozone in China on snap bean genotypes by using ethylenediurea (EDU). Environ. Pollut. 205, 199-208.

Yuan, X.Y., Calatayud, V., Gao, F., Fares, S., Paoletti, E., Tian, Y., Feng, Z.Z., 2016. Interaction of drought and ozone exposure on isoprene emission from extensively cultivated poplar. Plant Cell Environ. 39, 2276-2287.

Zhu, X.M., Zhang, W., Chen, H., Mo, J.M., 2015. Impacts of nitrogen deposition on soil nitrogen cycle in forest ecosystems: a review. Acta Ecol. Sin. 35, 35-43. 